Lina Marcinkevičiūtè

Aleksandras Stulginskis University, Lithuania e-mail: Lina.Marcinkeviciute@asu.lt

Jan Žukovskis

Aleksandras Stulginskis University, Lithuania e-mail: Jan.Zukovskis@asu.lt

Janusz Sasak

Uniwersytet Jagielloński w Krakowie e-mail: janusz.sasak@uj.edu.pl

\title{
ZARZACDZANIE ZASOBAMI NATURALNYMI W ZRÓWNOWAŻONYM ROZWOJU WSI NA PRZYKŁADZIE STAROSTWA NA LITWIE
}

\section{Abstract \\ Managing Natural Resources in Sustainable Development of Rural Areas on the Example of the Community in Lithuania}

The publication presents the issues of sustainable development of rural areas in the context of effective resource management. The issues of their protection and sustainable use were combined, taking into account the requirements of various areas (economic, social, cultural, legal and environmental protection). The main types of resources, functions and significance related to their use were analyzed. The consequences of changes in the environment, as well as the possibilities of solving and possible threats to the most current problems were determined. Attention was paid to the most important environmental components - air, water, climate, landscape and biodiversity problems.

The publication emphasizes the sustainable management of natural resources - the use of natural resources will bring many benefits to inhabitants of rural areas. A study evaluating the status of natural resources, management measures and value for the sustainable development of the Zasliai Community in the Kaisiadoris region has been described here. The study identifies and justifies the directions of improvement of natural resources management, in accordance with the components of sustainable development (economic, environmental and socio-social).

Keywords: management of natural resources, management based on the needs of the community, sustainable development of the rural areas. 


\section{Streszczenie}

W publikacji zaprezentowano problematykę zrównoważonego rozwoju obszarów wiejskich w kontekście efektywnego zarządzania zasobami. Połączono kwestie ich ochrony i zrównoważonego wykorzystywania, uwzględniając wymagania różnych sfer (ekonomicznej, społecznej, kulturowej, prawnej i ochrony środowiska). Analizie poddano główne rodzaje zasobów, funkcje i znaczenie związane z ich wykorzystywaniem. Określono konsekwencje zmian w środowisku, a także możliwości rozwiązania i możliwe zagrożenia najbardziej aktualnych problemów. Najwięcej uwagi poświęcono najważniejszym składnikom środowiska - powietrzu, wodzie, klimatowi, krajobrazowi i problemom różnorodności biologicznej.

W publikacji akcentowane jest zrównoważone zarządzanie zasobami naturalnymi - korzystanie z zasobów naturalnych przyniesie wiele korzyści obszarom wiejskim i ich mieszkańcom. Zostało tu opisane badanie oceniające stan zasobów naturalnych, środki zarządzania i wartość dla zrównoważonego rozwoju starostwa Žasliai, w rejonie Kaisziadorskim (Kaišiadoris). W opracowaniu wskazano i uzasadniono kierunki doskonalenia zarządzania zasobami naturalnymi, zgodnie z komponentami zrównoważonego rozwoju (ekonomicznym, ochrony środowiska i społeczno-socjalnym).

Słowa kluczowe: zarządzanie zasobami naturalnymi, zarządzanie oparte na potrzebach społeczności, zrównoważony rozwój wsi.

\section{Wstęp}

Rozwój ekonomiczno-gospodarczy wsi i stosowane w tym celu środki mają istotny wpływ na stan i funkcjonalność zasobów naturalnych. Stan środowiska i racjonalne jego wykorzystanie wpływa również na rozwój innych sektorów gospodarczych. Zarządzanie zasobami naturalnymi na obszarach wiejskich to skomplikowany proces, który integruje różne zasoby wsi, by stworzyć ogólny potencjał rozwoju miejscowości [Aleksandravičius, 2011]. Z powodu efektu synergii pomiędzy zarządzaniem zasobami naturalnymi a rozwojem innych obszarów aktywności ludzkiej, tworzy się wyraźny wkład kształtujący rozwój potencjału miejscowości. Układ ten ma znaczenie nie tylko dla rozwoju działań ekonomicznych czy miejscowej produkcji, ale też jest ważny dla tworzenia wizerunku, zwiększania atrakcyjności i przyciągania inwestycji. Pojmowanie miejscowego potencjału na zasadzie analizy zasobów decyduje o możliwościach i problemach, a także o różnorodności ich rozwiązania [Baležentis, 2011]. Duży wpływ na zrównoważony rozwój obszarów wiejskich mają nie tylko wielkość zasobów, ich jakość czy znaczenie dla miejscowości, ale też strategiczne planowanie, wsparcie miejscowej władzy, inwestycje w infrastrukturę, działania marketingowe i decyzje zarządzających.

Wsparcie finansowe było i jest ważnym instrumentem chroniącym zasoby naturalne każdego kraju i rozwijającym konkurencyjność obszarów wiejskich przez różnorodne formy działalności ekonomicznej. Zarządzanie zasobami naturalnymi powinno opierać się nie tylko na chęciach osób zainteresowanych, ale również na rzetelnej wiedzy niezbędnej do zidentyfikowania stanu i problemów 
środowiska oraz umiejętności rozwiązywania problemów. Dlatego też za cel niniejszego opracowania przyjęto ustalenie i uzasadnienie kierunków dokonalenia zarządzania zasobami naturalnymi. Realizując cel, zbadano zarządzanie zasobami naturalnymi i zasady określające zrównoważony rozwój obszarów wiejskich w starostwie Žasliai i przygotowano rekomendacje dla zarządzania zasobami naturalnymi. Na potrzeby opracowania wykorzystano analizę literatury przedmiotu, analizę dokumentów starostwa oraz stosowne ustawy i rozporządzenia, przeprowadzono wywiad strukturalny oraz wykonano stosowne analizy porównawcze.

\section{Istota i cel zarządzania zasobami naturalnymi w zrównoważonym rozwoju wsi}

W literaturze przedmiotu podkreśla się, że zrównoważone zarządzanie zasobami naturalnymi to część zrównoważonego (ekonomicznie, w ramach ochrony środowiska i społecznie) rozwoju obszarów wiejskich. W związku z tym przyjąć należy, że prawidłowo wykorzystane zasoby naturalne mogą przynosić korzyści obszarom wiejskim i ich mieszkańcom. Z badań [Benoit, Charles, 2012] wynika, że trwałe wykorzystywanie zasobów naturalnych wiąże się z koniecznością ich ochrony dla dobra regionu. Brak działań ochronnych prowadzi bowiem do dewastacji środowiska, i w konsekwencji do braku możliwości wykorzystania potencjału dostarczającego produkty najwyższej jakości. Daje się również zauważyć wówczas brak integracji pomiędzy sprawnym zarządzaniem regionem a utrzymaniem stanu zasobów naturalnych. Dążąc do tego, by efektywnie wykorzystać lokalne zasoby naturalne, konieczne jest poświęcanie szczególnej uwagi planowaniu infrastruktury i kontroli wykorzystania zasobów. Według Grundey [2012], takie czynniki zarządzania jak dobre planowanie, dostosowanie odpowiednich metod zarządzania i kontrolowanie mają silnie pozytywny wpływ na stan środowiska. Nie są jednak wystarczające dla zapewnienia zrównoważonego rozwoju. Ważne jest uzupełnienie tych działań podstawowymi zasadami zarządzania zasobami naturalnymi:

- efektywnością (mało sporów i mało starań, by utrzymać porządek organizacyjny);

- stabilnością (umiejętność „przyjmowania” zaprogramowanych zmian, inwestycje w nowe technologie);

- odpornością (umiejętność odpowiedniego reagowania na niespodziewane i nagłe zakłócenia zewnętrzne);

- prawidłowością (przejrzysta działalność).

Według Grant [2010], gdy środowisko zewnętrzne jest w stanie ciągłych zmian, wewnętrzne zasoby powinny być stabilnym fundamentem, na którym opiera się strategia rozwojowa. Dlatego po przeanalizowaniu lokalnych zasobów można ocenić ich stan, znaczenie dla społeczności lokalnej czy starostwa (samorządu).

Analizując jakość zmian środowiska pod kątem ich mocnych i słabych stron, możliwości rozwiązania najpilniejszych spraw i eliminacji zagrożeń, najwięcej 
uwagi w niniejszym opracowaniu poświęcono najważniejszym składnikom środowiska - powietrzu, wodzie, krajobrazowi i zagadnieniom biologicznej różnorodności. Z analizy literatury przedmiotu [Herriges, Kling, 2012; Krankalis, Anzelytė, 2013] wynika, że podstawowa klasyfikacja zasobów naturalnych obejmuje siedem rodzajów. W Tabeli 1 przedstawiono rodzaje zasobów naturalnych, ich funkcje i wskaźniki powiązane z wykorzystaniem z zasobów naturalnych.

Tabela 1

Rodzaje, funkcje i wskaźniki wykorzystania zasobów naturalnych

\begin{tabular}{|c|c|c|}
\hline $\begin{array}{l}\text { Rodzaj } \\
\text { zasobów } \\
\text { naturalnych }\end{array}$ & $\begin{array}{l}\text { Korzystanie } \\
\text { z funkcji zasobów natural- } \\
\text { nych }\end{array}$ & $\begin{array}{l}\text { Przykłady indykatorów związanych użytkiem } \\
\text { zasobów naturalnych }\end{array}$ \\
\hline \multirow{3}{*}{ Gleba } & Surowiec/na żywność & $\begin{array}{l}\text { Zamiana energii słonecznej na jedzenie, biomasę } \\
\text { dla paszy, materiały budowlane i inne }\end{array}$ \\
\hline & Schronienie & $\begin{array}{l}\text { Odpowiednia przestrzeń dla hodowli roślin } \\
\text { i zwierząt }\end{array}$ \\
\hline & Zasoby genetyczne & Zachowanie różnorodności kultur roślinnych \\
\hline \multirow{2}{*}{ Słońce } & Dla energetyki & $\begin{array}{l}\text { Do produkcji elektryczności i ogrzewania po- } \\
\text { mieszczeń }\end{array}$ \\
\hline & $\begin{array}{l}\text { Do potrzeb codziennych, } \\
\text { przemysłu }\end{array}$ & Do nagrzewania wody, suszenia \\
\hline \multirow{3}{*}{$\begin{array}{l}\text { Powietrze, } \\
\text { środowisko } \\
\text { i klimat }\end{array}$} & W gospodarce & Żywność, tempo budowy, praca transportu \\
\hline & W rekreacji & $\begin{array}{l}\text { Jakość powietrza, odzyskanie sił duchowych } \\
\text { i fizycznych }\end{array}$ \\
\hline & W energetyce & $\begin{array}{l}\text { Do produkcji energii mechanicznej i elektrycz- } \\
\text { ności }\end{array}$ \\
\hline \multirow{4}{*}{ Woda } & W potrzebach codziennych & $\begin{array}{l}\text { Woda do picia, gotowania, mycia się, prania, } \\
\text { polewania ogrodów i trawników w miejscach } \\
\text { przeznaczonych do rekreacji }\end{array}$ \\
\hline & $\begin{array}{l}\text { Dla obiektów użyteczności } \\
\text { publicznej }\end{array}$ & $\begin{array}{l}\text { Dla hoteli, szkół, szpitali i innych obiektów } \\
\text { przeznaczonych do użytku komercyjnego i nie- } \\
\text { komercyjnego }\end{array}$ \\
\hline & Dla energetyki & Woda, by otrzymać energię \\
\hline & Dla przemysłu & $\begin{array}{l}\text { Dla rolnictwa, rybołówstwa, przemysłu, chło- } \\
\text { dzenia }\end{array}$ \\
\hline
\end{tabular}




\begin{tabular}{|l|l|l|}
\hline \multirow{4}{*}{ Krajobraz } & Dla kultury & $\begin{array}{l}\text { Dla uformowania miejscowej kultury, wyróżnie- } \\
\text { nia miejscowości }\end{array}$ \\
\cline { 2 - 3 } & Dla rekreacji & Dla spędzenia czasu wolnego, samorozwoju \\
\cline { 2 - 3 } & Dla turystyki & Odpoczynek, ekonomiczna korzyść dla kraju \\
\hline \multirow{2}{*}{$\begin{array}{l}\text { Zasoby żywej } \\
\text { przyrody }\end{array}$} & Dla zwierząt & $\begin{array}{l}\text { Do podtrzymania ekosystemu, jedzenia, polo- } \\
\text { wania }\end{array}$ \\
\cline { 2 - 3 } & Dla roślin i grzybów & Dla drewna, jedzenia, rekreacji, fotosyntezy \\
\hline \multirow{3}{*}{ Minerały } & Na budowę & Piasek, żwir, dolomit, wapień \\
\cline { 2 - 3 } & Dla energetyki & Nafta, olej napędowy, gaz \\
\cline { 2 - 3 } & Dla produkcji materialnej & Glina, torf, podziemna woda, sól kamienna \\
\hline
\end{tabular}

Źródło: opracowanie własne.

Z przedstawionego zestawienia wynika, że wszystkie rodzaje zasobów naturalnych mają zasadnicze znaczenie dla ludzkiego zdrowia i dobra, a same zasoby spełniają funkcję zaopatrzenia z regulowaniem ilości opadów. Funkcje kulturowe obejmują piękno, natchnienie i odpoczynek, a to przyczynki do duchownego dobra. Dodatkowe funkcje obejmują proces formowania gleby, fotosyntezę i cykl elementów odżywiania, które są podstawą wzrostu i produkcji [Bukantis, Gedžiūnas, 2008].

Przypuszcza się [Dargužas, 2011; Kisielienė, 2012; Skurdenienė, Šeškauskaitė, 2010], że mieszkańcy, którzy są aktywnymi obywatelami, są bardziej skłonni do ochrony środowiska, biorą udział w akcjach sprzątania, a także zauważa się u nich wzrost przedsiębiorczości (np. rozwijają poszczególne gałęzie gospodarcze, takie jak turystyka, usługi, wysokie technologie; ma to mniejszy negatywny wpływ na środowisko niż wtedy, gdy rozwija się tradycyjny przemysł). W literaturze przedmiotu jednoznacznie wskazuje się [Lynam, Norfolk, 2013; Mont, Bleischwitz, 2012], że zarządzanie zasobami naturalnymi oparte na potrzebach wspólnoty jest nieodłącznym składnikiem rozwoju lokalnego. Potrzeby te znajdują swoje odzwierciedlenie w miejscowej strategii, realizowanych zadaniach, procesach ochrony środowiska, a także zadowoleniu mieszkańców. 


\section{Ocena stanu zasobów naturalnych w starostwie Žasliai}

To, jak ważne są starostwa, najbardziej jest widoczne podczas procesu planowania, czyli podczas przygotowywania strategicznych planów, które stanowią podstawę zrównoważonego rozwoju. Starostwa są najbliżej mieszkańców, biznesu, szkół, organizacji pozarządowych, dlatego mogą zagłębić się w problemy, przewidzieć wyniki projektów i optymalnie wykorzystać posiadane zasoby. Bardzo ważne jest zrozumienie, że zrównoważony rozwój oznacza, iż mówimy o konkretnej sytuacji i o konkretnym czasie, dążąc do celów rozwoju miejscowego, i że ma to być związane z ochroną zasobów naturalnych. Rozwijając obszary wiejskie, należy opierać się na zasadach zarządzania, które oszczędzają zasoby naturalne. Zachęcać mieszkańców, by mniej zanieczyszczali środowisko, bardziej skutecznie korzystać z miejscowych zasobów naturalnych, inwestować w nowe technologie i tworzyć nowe produkty czy usługi, bazując na zasadach ekologiczności.

Badanie autorów publikacji zostało wykonane w rejonie Kaisziadoris, w starostwie Žasliai. Dążono do tego, by ustalić stan zasobów naturalnych, środki zarządzania i wartość dla zrównoważonego rozwoju obszaru. Wykonano: analizę zasobów naturalnych znajdujących się w starostwie i ocenę stanu zasobów; zidentyfikowano ważne czynniki zarządzania zasobami i ustalono, jaki jest ich związek z wynikami działalności.

Pierwszy etap badania - analiza dokumentów - pozwolił na wyciągnięcie logicznych wniosków, przy wzięciu pod uwagę treści przeanalizowanych materiałów (dokonano analizy treści dokumentu). Drugi etap badania stanowiła analiza porównawcza - ta metoda pozwoliła na zidentyfikowanie sfer i sposobów działania, które należy doskonalić, którymi warto przekazać pomyślne doświadczenia. $\mathrm{Z}$ tej metody skorzystano, ustalając zalety i możliwości wykorzystania miejscowych zasobów naturalnych, a także opisując środki zarządzania zasobami i składniki koncepcji zrównoważonego rozwoju, które pozwolą na osiągnięcie zrównoważonego rozwoju wsi. Trzecim etapem był wywiad strukturyzowany. Zostały ustalone konkretne pytania i kolejność ich zadawania. Respondenci należeli do grupy wykwalifikowanych specjalistów, mających długoletnie doświadczenie zawodowe i mogących podać dokładne i wyczerpujące informacje o tym, jakie zasoby naturalne są w konkretnym miejscu i jak nimi zarządzać. Najważniejsze było wyłonienie najbardziej aktualnych problemów zarządzania i korzystania z zasobów naturalnych.

Analiza stanu zasobów naturalnych w starostwie

Gleba. W starostwie gleba jest bardzo różna. Największą część zajmuje gleba darniowo-bielicowa; $88,34 \%$ gleby jest o niskim i bardzo niskim poziomie azotu. Gleba o wysokim i bardzo wysokim poziomie azotu stanowi 11,66\%. Ziemie są intensywnie uprawiane. Grunty o różnym przeznaczeniu zajmują około $68 \%$ obszaru starostwa. Ogółem obszar uprawianej ziemi to $56,7 \%, 1 \%$ - to sady, 23,8\% 
- pastwiska i łąki, drogi i strefa chroniona zajmują 5,5\% terytorium, inne ziemie - 13\% [Zastosowanie zaawansowanych technologii..., 2013].

Energia słoneczna. Promienie słońca są wystarczającym źródłem, by efektywnie używać niewielkiego kolektora słonecznego. Aby zaspokoić potrzeby na ciepłą wodę w domu jednorodzinnym, należało by zainstalować kolektor wielkości $20 \mathrm{~m}^{2}$; w bloku potrzebny jest kolektor $60 \mathrm{~m}^{2}$. W starostwie ogólnie ze słonecznej i geotermalnej energii korzysta się tylko na $0,6 \%$. Bazując na danych ze studium wykonalności z dostawy energii cieplnej, ustalono, że mniej niż 0,5\% mieszkańców domów jednorodzinnych z ogrzewaniem i gorącą wodą ma zainstalowaną pompę ciepła, a z energii słonecznej korzystają nieliczni.

Powietrze. Na terytorium starostwa jeżdżą samochody osobowe, a także wyspecjalizowany transport usługowy, nieopodal jest międzynarodowa droga kolejowa. W latach 2016-2017 zarejestrowano tu 18 tysięcy 920 samochodów. W opracowanym planie środków polepszania jakości powietrza priorytety są następujące: czyszczenie i nawilżanie ulic i bocznych dróg, kontrola miejsc budowy i transportu, który je obsługuje, zalesianie problematycznych gruntów, a także kontrola obowiązujących dokumentów regulujących środowisko. Obecnie, gdy zasoby energetyczne są coraz droższe, dynamicznie rozwija się sieć elektrowni wiatrowych produkujących energię; ten sposób produkcji stał się dostępny dla wielu gospodarstw. W specjalnym planie lokalizacji elektrowni wiatrowych zaplanowany został rozwój sieci elektrowni wiatrowych w starostwie. W ogólnym planie mają powstać małe, do $250 \mathrm{~kW}$, elektrownie wiatrowe.

Woda. W starostwie jednym z najważniejszych zasobów przyrody są złoża wody i chronione terytoria wokół nich. Ochrona tych zasobów i zachowanie zasad zrównoważonego rozwoju mogą stworzyć ekonomiczny pożytek dla starostwa. Założenie jest takie, iż ta grupa zasobów jest wystarczająco ważna na skalę miejscową. Liczne jeziora przyciągają mieszkańców miast, jednak niezbyt dobrze rozwinięty sektor usług publicznych nie generuje większego ruchu turystycznego. Na terytorium są rzeki, rzeczki, jeziora, stawy, zbiorniki wodne, kanały, rowy. Woda zajmuje około $1,9 \%$ całego terytorium.

Krajobraz. Krajobraz starostwa jest pagórkowaty. Został tu posadzony „Las Europy”. Od strony Žasli, skręcając w kierunku Čiobiškio, można trafić na prom przez Wilię. To jedyny taki prom na Litwie.

Zasoby żywej przyrody. Dla starostwa charakterystyczne są zwierzęta i rośliny tajgi i lasów szerokolistnych. Najwięcej jest tu właśnie lasów szerokolistnych i lasów świerkowych z elementami lasów szerokolistnych. Lasy zajmują 18,6\% terytorium. Do leśnictwa należy 644,5 ha lasu. Lasy gospodarcze stanowią 1074 ha terytorium, szkółki leśne - 109 ha. Jest pięć miejscowych rezerwatów, jeden rezerwat państwowy i cztery miejscowe pomniki przyrody. Terytoria chronione wynoszą 375 ha.

Minerały. W starostwie występują takie minerały, jak: żwir, piasek, glina i torf. Zbiorowiska piasku i żwiru zajmują 5,1 ha, kamieniołom - 5,2 ha. Żwir i piasek najczęściej są wykorzystywane do produkcji materiałów budowlanych, z torfu wytwarza się kompost (dla poprawienia jakości gleby), a także wazony do sadzonek i materiały do pakowania. 
Podsumowując: po ustaleniu przewagi konkurencyjnej i ocenie posiadanych zasobów, można ustalić środki, które pozwolą wzmocnić konkurencyjność miejsca, ale nie naruszą zasad zrównoważonego rozwoju obszarów wiejskich.

\section{Doskonalenie zarządzania zasobami naturalnymi w starostwie}

Bazując na teoretycznej analizie i wynikach badań praktycznych, zostały ustalone i uzasadnione kierunki zarządzania zasobami naturalnymi według składników zrównoważonego rozwoju (gospodarczego, ochrony środowiska i społeczno-kulturowego), a także zostały przygotowane praktyczne rekomendacje dla miejscowych działaczy (zob. Tabela 2).

Jak już wspomniano, 68\% terytorium starostwa stanowi ziemia różnego przeznaczenia. $\mathrm{Z}$ tej całości grunty uprawne stanowią $56,7 \%$, sady $-1 \%$, pastwiska i łąki 23,8\%, drogi i terytoria chronione 5,5\%, a inne ziemie - 13\%. Większość ziem nadających się do uprawy zostało zmeliorowanych, stwarzając w ten sposób lepsze warunki dla rolnictwa. W ogólnym planie starostwa zostały przewidziane zmiany zasad korzystania z ziemi, uzasadnione obecnymi tendencjami rozwoju terytorium przeznaczonego dla rolnictwa i terytorium mieszkalnego. Część nieżyznej lub tej mniej przydatnej do uprawiania gleby zostanie zalesiona. Zaplanowano też przekazanie ziemi według bieżących potrzeb, np. na eksploatowanie minerałów lub rozwój obszarów mieszkalnych. Może to mieć wpływ nie tylko na glebę, ale i na reżim wodny, przykładowo wtedy, gdy część gleby zostanie zlikwidowana podczas budowy lub podczas wydobywania minerałów. Jednak takie zmniejszanie obszarów ziemi przeznaczonej na uprawę roli nie będzie miało większego wpływu na rolnictwo i jego rozwój. Na pozostałych obszarach zostaną stworzone lepsze warunki dla intensywnej działalności rolniczej, zapewniając potrzebne środki ochronne dla gleby, zbilansowane nawożenie nawozami mineralnymi i organicznymi.

Energia słoneczna może tu być wykorzystywana na dwa sposoby: do produkcji elektryczności albo do produkcji ciepła (ogrzewanie wody kolektorami, bezpośrednie ogrzewanie budynków itd.). W starostwie tym kolektory słoneczne najlepiej byłoby wykorzystać do otrzymywania gorącej wody, czyli wielkość kolektora byłaby zależna od tego, ile gorącej wody dana osoba/instytucja by potrzebowały. Kolektory słoneczne pozwoliłyby na zdecydowaną oszczędność w tym względzie - do 70\% rocznych wydatków. Kolektory byłyby też odpowiednie dla osób posiadających otwarte lub kryte baseny. $Z$ danych pozyskanych od firm handlujących kolektorami słonecznymi wynika [UAB „Ekoplius”, 2016], że rodzina składająca się z dwóch do czterech osób musiałaby zapłacić za jeden system od 1,5 do 7 tysięcy euro. Najbardziej popularne i rozpowszechnione są systemy na dwa płaskie kolektory słoneczne, kosztujące około 2,3 tysiąca euro (z montażem). To jednak nadal dość duża inwestycja dla właścicieli prywatnych domów. 


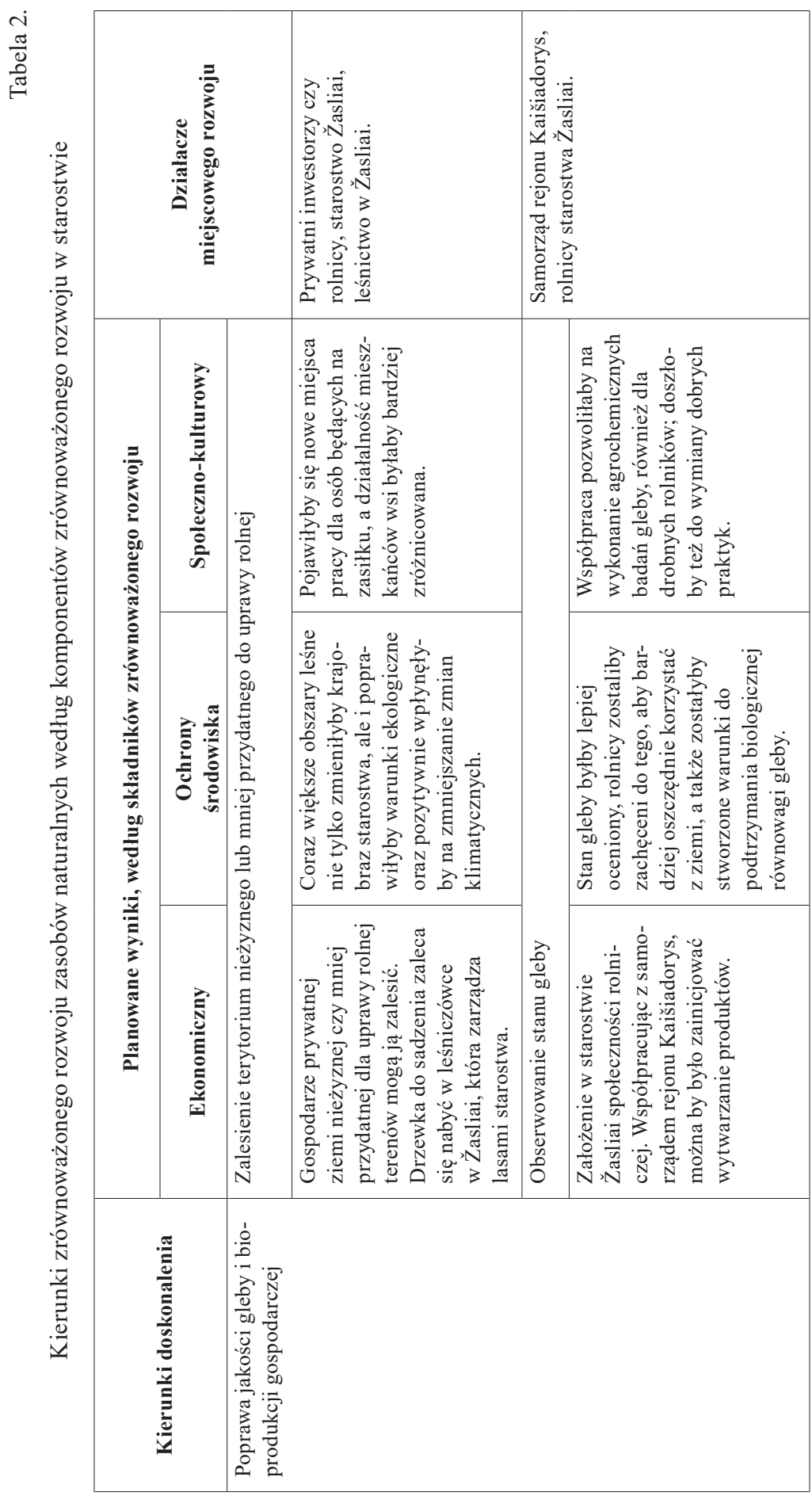




\begin{tabular}{|c|c|c|}
\hline \multicolumn{2}{|c|}{ 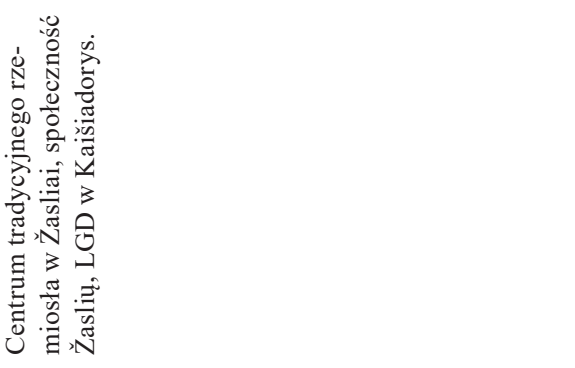 } & 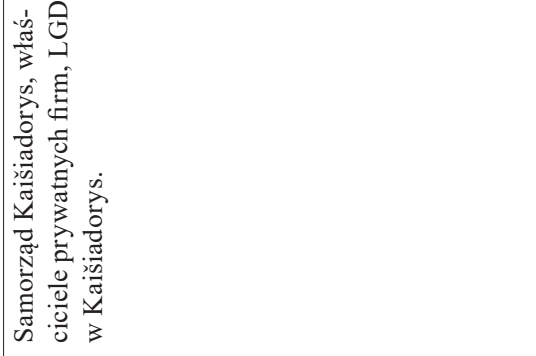 \\
\hline \multirow{3}{*}{ 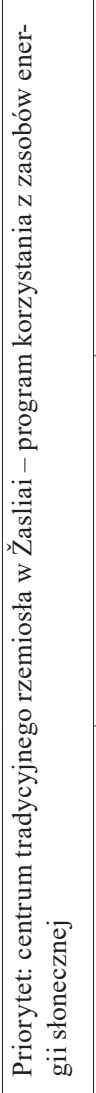 } & 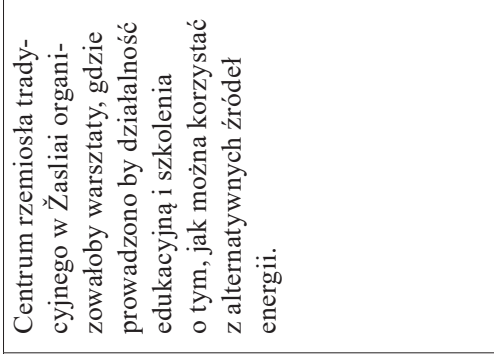 & 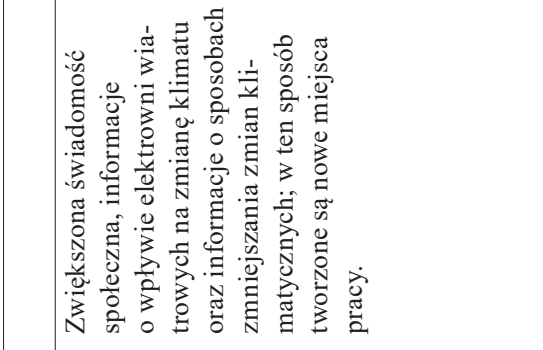 \\
\hline & 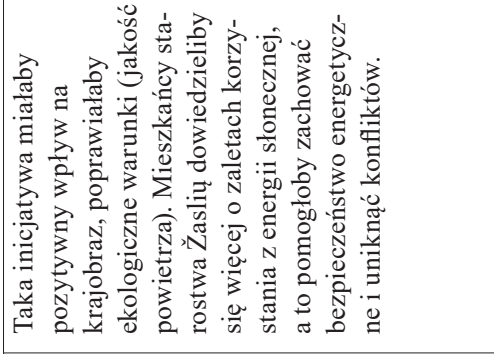 & 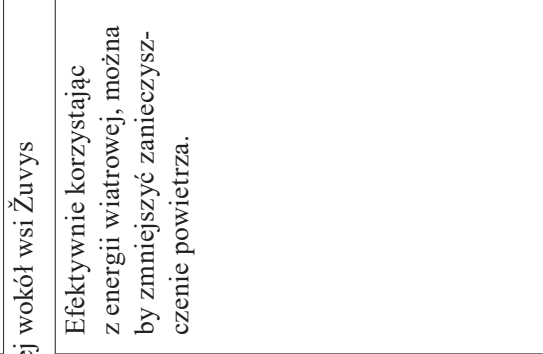 \\
\hline & 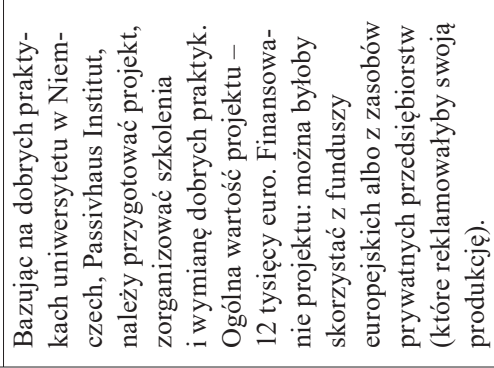 & 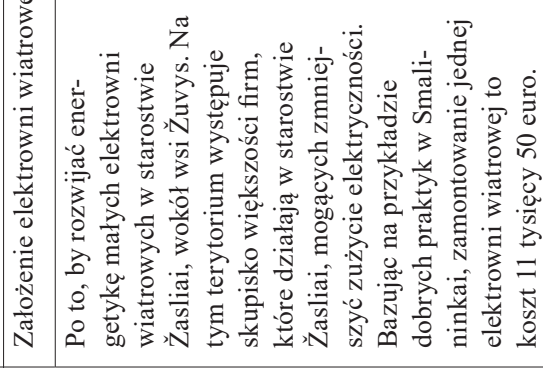 \\
\hline \multicolumn{2}{|c|}{ 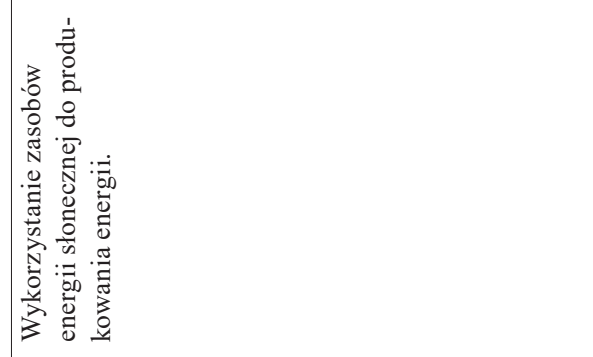 } & 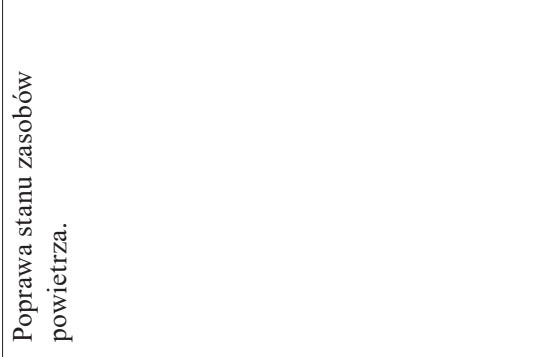 \\
\hline
\end{tabular}




\begin{tabular}{|c|c|c|c|}
\hline \multicolumn{2}{|c|}{ 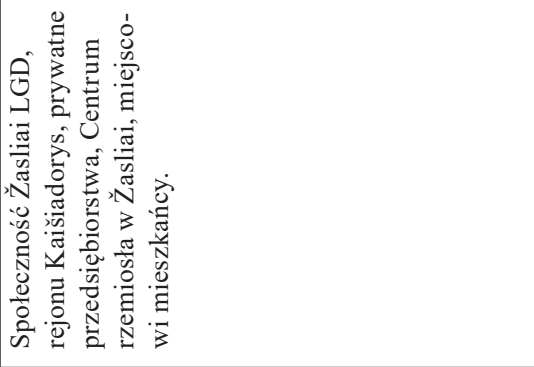 } & \multicolumn{2}{|c|}{ 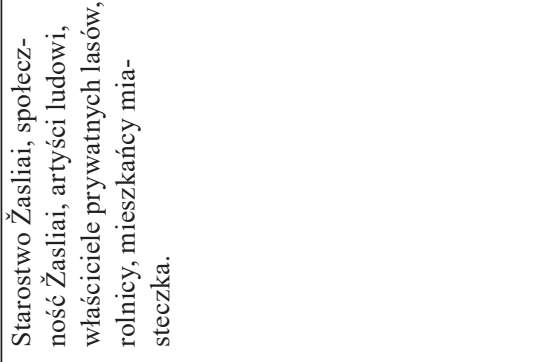 } \\
\hline \multirow{3}{*}{ 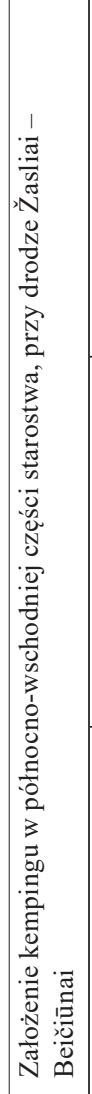 } & 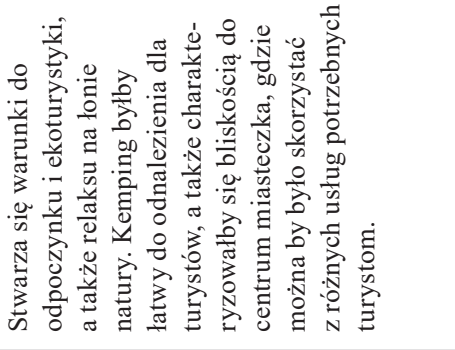 & \multirow{3}{*}{ 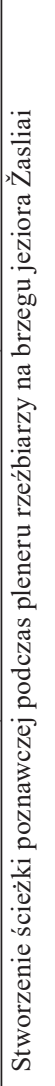 } & 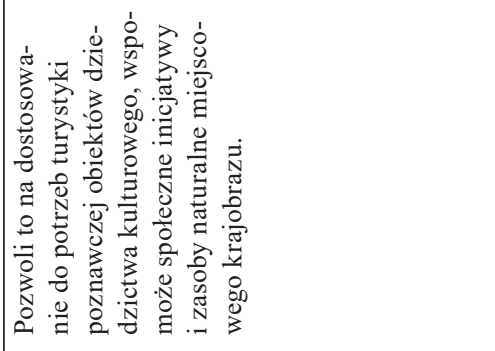 \\
\hline & 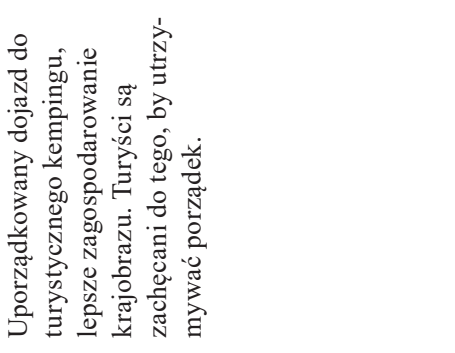 & & 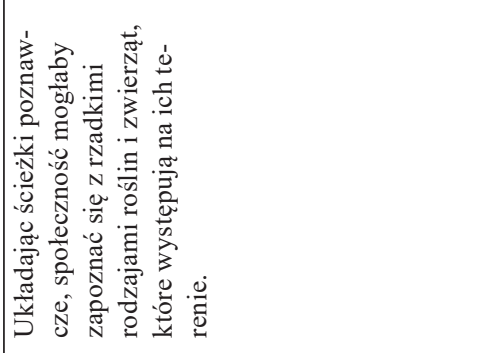 \\
\hline & 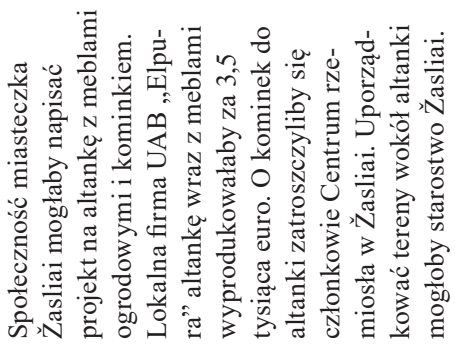 & & 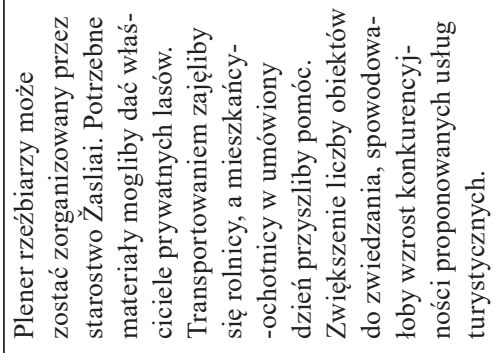 \\
\hline \multicolumn{4}{|c|}{ 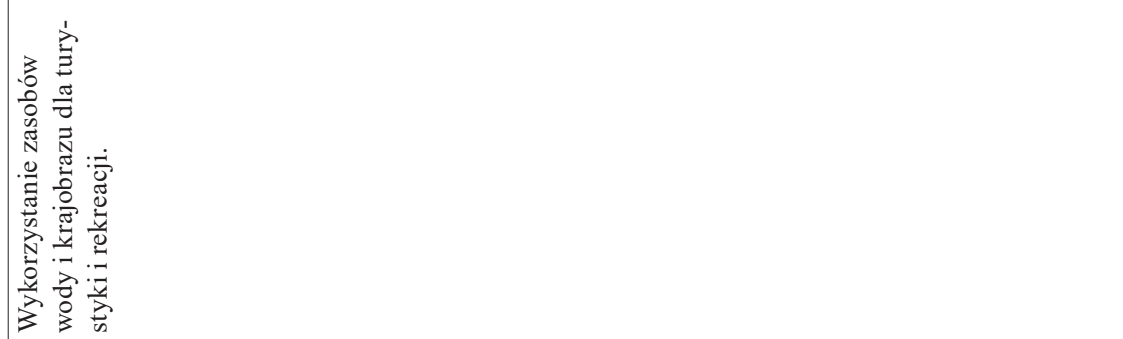 } \\
\hline
\end{tabular}




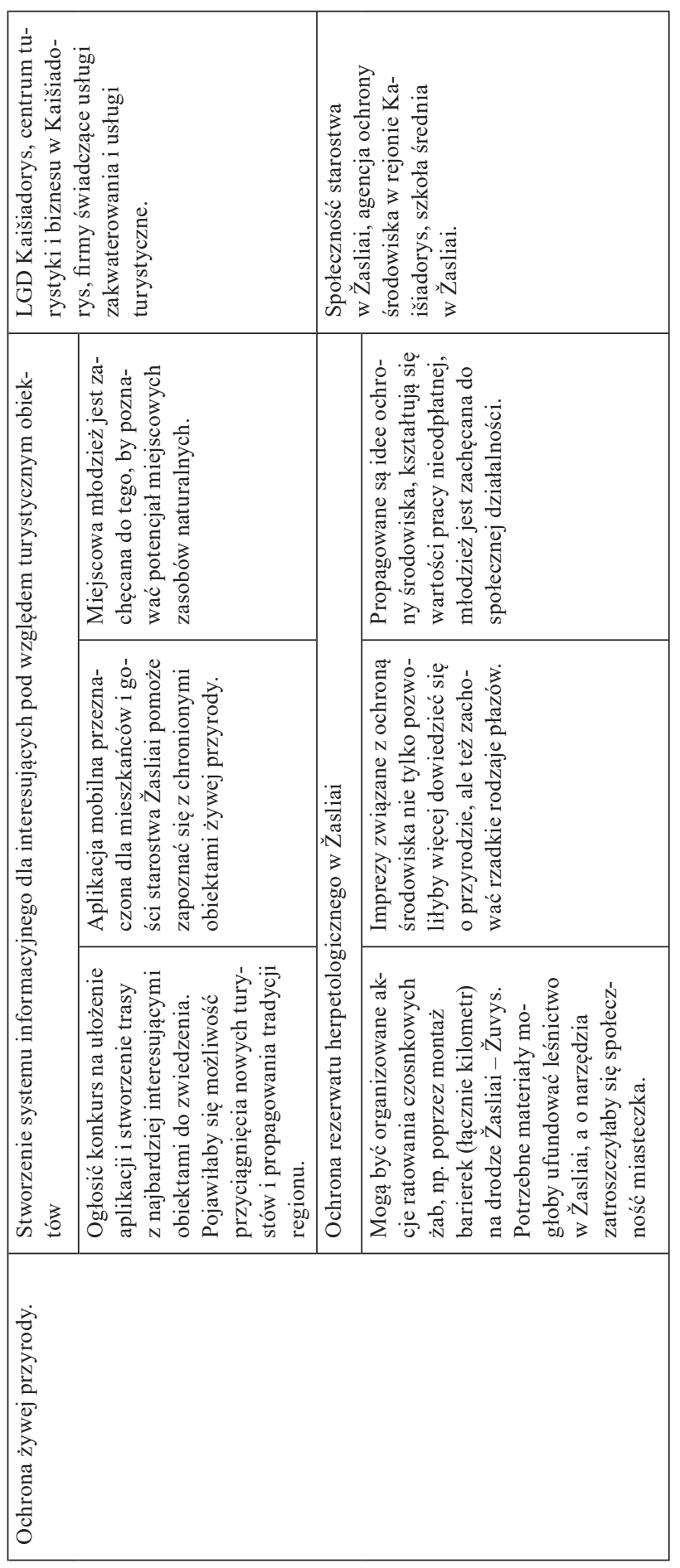

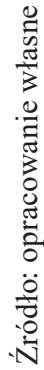


W starostwie już prawie zakończono realizację projektu „Tworzenie centrum tradycyjnego rzemiosła”. Centrum tradycyjnego rzemiosła to filia centrum kulturowego w Žasliai, które udostępnia pomieszczenia. Można się będzie tu nauczyć, jak zachować tradycyjne rzemiosła, wziąć udział w warsztatach, przyjść na konsultacje itp. W ramach działania centrum można byłoby wprowadzić program dotyczący źródeł energii odnawialnej. Organizując warsztaty, szkolenia, centrum rzemiosła mogłoby się przyczynić do wykorzystania potencjału energii słonecznej. Inżynieryjne rozwiązania infrastrukturalne miałyby pozytywny wpływ na powietrze, wodę i glebę. Rozwijając scentralizowaną dostawę ciepła, dobierając rodzaje paliwa, które mniej zanieczyszczałyby środowisko, sprawiłoby, że jakość powietrza byłaby lepsza. Po przyłączeniu coraz większej liczby użytkowników do scentralizowanego systemu zaopatrzania w wodę i odprowadzania ścieków, nastąpiłaby poprawa jakości wód powierzchniowych.

Na północno-wschodnim terytorium, przy drodze Žasliai - Beičiūnai, proponuje się założenie kempingu, tak by przyciągnąć więcej turystów. Miejsce łatwe do znalezienia dla podróżnika byłoby blisko centrum miasta. Na odpoczynek przy wodzie można wykorzystać dwa jeziora znajdujące się w miasteczku - północną część jeziora Statkūniškio na plażę, a jezioro w Žasliai - jako podstawowe miejsce rekreacji i spędzania czasu wolnego dla mieszkańców. W północnej części miasteczka Žaslių, gdzie znajduje się zielona strefa otoczona miastem, proponuje się założenie strefy rekreacyjnej, ze stadionem i boiskami do tenisa itp. Ta część byłaby przeznaczona dla aktywnego wypoczynku i rozrywek w wodzie, z możliwością kąpieli. W zachodniej części jeziora Žasliai, w miejscu zatoki, można by ulokować infrastrukturę pomocną w organizowaniu imprez i dni świątecznych przez miasto. W tym miejscu może też zostać założona przystań dla łódek. Jedną z największych wartości tego terenu jest wyjątkowy krajobraz, a jedną z największych zalet panoramy krajobrazu - to, że nie ma tu dużych budynków przemysłowych, służących hodowli bydła, wieży silosu itd. Do uporządkowania, korzystania i ochrony przyrody na terytorium, proponuje się stosować następujące kierunki: zachowanie i ochrona obecnego, naturalnego rodzaju krajobrazu, upiększanie i zwiększanie liczby elementów odtwarzających naturalność krajobrazu. Te kierunki będą rozwijane, poprzez zwiększanie ilości roślin w zatokach rzek, tworzenie terenów rekreacyjnych, niezabudowanych, dla odpoczynku i rozrywki przy jeziorach.

Jedna z możliwości wykorzystania krajobrazu to ścieżka etnograficzna na brzegu głównego jeziora Žasliai, stworzona przez rzeźbiarzy wykonujących figury z drewna. Stanowiłaby rozrywkę nie tylko dla mieszkańców, ale też dla gości miasteczka, którzy zapoznaliby się z etnografią miasteczka Žasliai, sztuką ludową i tradycjami. Najważniejsze, by skorzystać tu z zasobów naturalnych, które są w starostwie. Współpraca z leśnictwem w Žasliai i właścicielami prywatnych lasów mogłaby być źródłem surowca dla sztuki. Przedstawiciele prywatnego biznesu, którzy eksploatują kamieniołom znajdujący się w południowo-wschodniej części jeziora, mogliby wypożyczyć sprzęt przeznaczony do kopania i równania. Taki twórczy partnerski projekt połączyłby zawodowców ze sfer sztuki, oświaty i socjalnej. W rezultacie nastąpiłaby poprawa krajobrazu, a także udałoby się 
zintegrować zasoby naturalne znajdujące się na terenie starostwa. Proponuje się zachęcać do dbania o dobrobyt społeczności starostwa poprzez stwarzanie równych możliwości tworzenia sztuki i uczestniczenia w działalności kulturowej.

Ważne, aby do planu rozwoju starostwa zostały włączone środki kulturowe zachęcające do dbania o zdrowie i dobro mieszkańców. Za przygotowanie projektu odpowiedzialne są: starostwo i organizacje społecznościowe. Takie projekty sztuki i kultury mogą być finansowane przez ministerstwo oświaty i ochrony zdrowia. Ważna jest tu współpraca z samorządem i lokalnymi grupami. Inicjatywa społeczności mogłaby zmniejszyć wydatki związane z finansowaniem, np. poprzez organizację plenerów dla rzeźbiarzy.

Podsumowując: propozycje na doskonalenie zarządzania zasobami pozwolą racjonalnie i kompleksowo spojrzeć na możliwe priorytety rozwoju starostwa czy przygotowywane projekty, które należy zainicjować, dążąc do zrównoważonego rozwoju wsi poprzez zarządzanie zasobami naturalnymi. Aktualne jest to, że proponowane praktyczne rekomendacje są bardzo rzeczywiste i można je zrealizować, tworząc infrastrukturę dla potrzeb społeczeństwa i wykorzystując zasoby naturalne, które są w starostwie.

\section{Wnioski}

1. Zasoby naturalne znajdujące się w konkretnej miejscowości mogą stworzyć przewagę konkurencyjną, jednakże obowiązkowe jest odpowiednie nimi zarządzanie, tak by korzystanie z nich nie naruszyło zrównoważonego rozwoju obszarów wiejskich.

2. Po wykonaniu analizy zasobów naturalnych ustalono, że w starostwie ziemie są mocno uprawiane, a to negatywnie wpływa na zasoby gleby. Zasoby energii słonecznej są używane mało albo nieefektywnie, zła jakość powietrza wpływa na prywatny transport. Jakość wody w jeziorach jest dobra, jednakże brakuje miejsca przeznaczonego na rekreację i przyciąganie turystów; ochrona żywej przyrody została zapewniona.

3. Zalesienie mniej żyznej gleby i obserwowanie stanu gleby pomogłyby ulepszyć jakość powietrza, miałyby pozytywny wpływ na krajobraz i polepszyłyby warunki ekologiczne.

4. Zrównoważony rozwój starostwa, oparty na korzystaniu z zasobów energii odnawialnej, mógłby być dobrym środkiem do kompleksowego wykorzystania wiatru i słońca. Obejmuje to nie tylko produkcję energii, ale też jej dostawę i użytkowanie.

5. Celowe korzystanie z wody i krajobrazu pozwoliłoby na zrównoważony rozwój jeziora Žasliai, poprzez dostosowanie go do rekreacji i odpoczynku. Działalność sportowa na tym terytorium pozwoliłaby przyciągnąć więcej mieszkańców, a także gości miasta, którzy korzystaliby z usług świadczonych na wybrzeżu jeziora (wyżywienie, zakwaterowanie i inne). 


\section{Bibliografia}

Aleksandravičius A., Žukovskis J. (2011), Kaimo bendruomeniu raida ir ju veiklos tikslai: siekiant darnumo visuomeneje (Rozwój społeczności wiejskich i cele ich działań: osiągnięcie zrównoważonego rozwoju w społeczeństwie), [dostęp 5 maja 2016 r.]. Link: http:// etalpykla.lituanistikadb.lt/fedora/objects/LT-LDB-0001:J.04 2011 1367168789998/data streams/DS.002.0.01.ARTIC/content.

Baležentis A. (2011), Kaimo vietovių raida ir modeliai: darnaus vystymo požiūris (Rozwój obszarów wiejskich i wzorce: podejście oparte na zrównoważonym rozwoju), [dostęp 19 marca 2016 r.]. Link: http://vadyba.asu.1t/26/31.pdf

Benoit R., Charles C. (2012), Configurational Comparative Methods Qualitative Comparative Analysis, [dostęp 10 maja 2016 r.]. Link: http://goo.gl/6gY9Qg.

Bukantis A., Gedžiūnas P. (2008), Lietuvos gamtine aplinka, būklè, procesai ir raida (Litewskie środowisko naturalne, stan, procesy i rozwój), [dostęp 24 kwietnia 2016 r.]. Link: http://193.219.133.6/aaa/pranesimai/Lietuvos_gamtine_aplinka_bukle_procesai_ir_raida.pdf.

Dargužas A. (2011), Interesu konfliktas sprendžiant klimato kaitos problema, jų mažinimas (Konflikt interesów w rozwiązywaniu problemów zmniejszania zmian klimatycznych). [interaktywny], [dostęp 14 kwietnia 2016 r.]. Link: http://vddb.library.lt/fedora/get/LT-eLABa-0001:E.02 2011 D_20110705_131620-62024/DS.005.0.01.ETD

Grant M. (2010), Contemporary Strategy Analysis and Cases [interaktyvus], [5 maja 2016 r.]. Link: http://books.google.lt/books?hl=lt\&lr=\&id=dXw6MkTCbeoC\&oi=fnd\&pg=PA2 $09 \& \mathrm{dq}=$ grant $+\mathrm{rm}+.+2010+$ contemporary + strategy + analysis\&ots $=8 \mathrm{gnBFECEZ} \& \mathrm{sig}=\mathrm{g}$ rfVztP9Kd6T2w8Cx8RObzsjCTY\&redir_esc $=y \# v=$ onepage $\& q=$ grant $\% 20 \mathrm{rm} \% 20 . \% 20$ $2010 \% 20$ contemporary\%20strategy $\% 20$ analysis $\& f=$ false.

Grundey D. (2012), Managing Sustainable Tourism in Lithuania: Dream or Reality?, [dostęp 17 kwietnia 2016 r.]. Link: http://www.tandfonline.com/doi/pdf/10.3846/13928619.2008.14.118-129.

Herriges J.A., Kling C.L. (2012), The Measurement of Environmental and Resource Values - Theory and Methods, [dostęp 3 maja 2016 r.]. Link:http://www.routledge.com/books/ details/9780415501583/.

Kisielienė G. (2012), Gamtiniu ištekliu, kraštovaizdžio ir bioịvairovès apsauga (Ochrona zasobów naturalnych, krajobrazów i różnorodności biologicznej) Kaunas: Technologija.

Krankalis R., Anzelytė R. (2013), Darnaus vystymosi nuostatu igyvendinimas kaimiškosiose savivaldybèse (Wdrażanie przepisów dotyczących zrównoważonego rozwoju w gminach wiejskich), [dostęp 24 kwietnia 2016 r.]. Link: http://vddb.library.lt/fedora/get/LT-eLABa0001:J.04 2013 ISSN_2029-8846.N_1_5.PG_40-52/DS.002.0.01.ARTIC.

Lietuvos Respublikos aplinkos ministerija (2001), Rio deklaracija: apie aplinka ir plètra (Deklaracja z Rio: środowisko i rozwój), [dostęp 17 maja 2016 r.]. Link: http://www.am.lt/ LSP/files/Agenda21.pdf.

Lietuvos Respublikos teritorijos bendrasis planas (Ogólny plan terytorium Republiki Litewskiej), [dostęp 20 kwietnia 2016 r.]. Link: http://www3.lrs.lt/pls/inter2/dokpaieska. showdoc_1?p_id=284909. 
Lietuvos Respublikos regioninès plètros įstatymas (Ustawa o rozwoju regionalnym Republiki Litewskiej), [dostęp 20 kwietnia 2015 r.] Link: : http://www3.1rs.lt/pls/inter3/dokpaieska. showdoc_1?p_id=298580.

Lynam T., Norfolk S. (2013), Review of Tools for Incorporating Community Knowledge, Preferences, and Values into Decision Making in Natural Resources Management, [dostęp 11 maja 2015 r.]. Link: http://www.mtnforum.org/sites/default/files/publication/files/1730. pdf.

Mont O., Bleischwitz R. (2012), Sustainable Consumption and Resource Management in the Light of Life Cycle Thinking, [dostęp 23 kwietnia 2016 r.]. Link: http://www.researchgate.net/profile/Raimund_Bleischwitz/publication/229588688_Sustainable consumption_and_resource_management_in_the_light_of_life_cycle_thinking/ links/54045e2f0cf23d9765a62369.pdf.

Zastosowanie zaawansowanych technologii i dobrych praktyk rolniczych $w$ rolnictwie i promocji na Litwie w celu zapobiegania zanieczyszczeniom pochodzącym z zasobów rolnych (Pažangių technologijų ir gerosios praktikos žemès ūkyje taikymas bei skatinimo Lietuvoje, siekiant išvengti aplinkos taršos iš žemès ūkio šaltiniu, studija) [dostęp 20 kwietnia 2016 r.]. Link: http://www.zum.lt/zum/m/m_files/wfiles/file1879.pdf.

Skurdenienė I., Šeškauskaitė D. (2010), Lyderiu vaidmuo Lietuvos kaime: ekonominio išsivystymo ir lyčiu lygybès aspektai (Rola liderów na litewskiej wsi: aspekty rozwoju gospodarczego i równości płci) [dostęp 4 maja 2016 r.]. Link:http://vddb.library.lt/fedora/get/LT-eLABa-0001:J.04 2010 ISSN_1648-9098.N_3_2_19.PG_39-48/DS.002.0.01.ARTIC. 